\title{
Expanding Agricultural and Rural Extension Roles for Sustainable Extension Practice in Nigeria
}

\author{
*Shimayohol Daudu and ${ }^{* *}$ Bauchi, B. M. \\ *Department of Agricultural Extension and Communication, \\ University of Agriculture, Makurdi. \\ ${ }^{* *}$ Ministry of Agriculture, Makurdi. \\ Email: shimayohol@yahoo.com \\ Mobile: +2348036058567
}

\begin{abstract}
The effect of globalization and the attendant privatization of the public sector of national economies of developing nations has profound effect on extension service delivery. This paper reviews present concept and challenges of extension and proposes future concerns of extension service. It concludes that extension educational service in Nigeria should be rendered as a hybrid of both public and private good. Public good extension should include such roles as provision of knowledge, skills and experience to HIVIAIDS orphans and training of farmers on how to reduce labour shortage due to the HIVIAIDS pandemic. On the other hand, extension service must strive to expand its traditional concept to that of private good to achieve economic sustainability. The expanded scope could include marketing extension, non-farm rural micro enterprise development, service to farmers' associations, technical extension service and urban extension. These services should be provided at a cost to ensure economic sustainability of extension service delivery.
\end{abstract}

Key words: Extension, expanded concept, economic sustainability.

\section{Introduction}

Agricultural extension is a system that provides farmers with technical advice required to increase their agricultural production and incomes and provides agricultural service organizations with information about farmers' conditions, constraints and priorities in order for these organizations to serve the farmers better (Baxter, 1989). According to Leagans (1961), the process of extension education is one of working with people, not for them; of helping people become self reliant, not dependent on others; of making people central actors in the drama, not stage hands or spectators; in short, helping people by means of education to put useful knowledge to work for them. Yet, Fresco (1999) noted that agricultural extension is sometimes depicted as a system that: provides unbiased advice; stimulates and promotes interaction among farmers; facilitates and supports a two-way flow of information between the extension staff, researcher and other sources of knowledge; and is enhanced by modern technology and good communication skills.

These definitions view extension as a means of introducing change with the hope that the change may be sustainable. The change is expected to be mediating through a trained agent of change, the extension agent, who is often publicly funded as is wont in most developing countries, including Nigeria. The services provided are often free of charge and with adequate persuasion. Public funded Extension has high pay-off though it takes time for this to materialize. Indeed, extension has economic ratio of return indicating its potential to bring about change (Birkhaeuser, Evenson and Feder, 1988). In Nigeria, public funded extension was 
able to improve the percentage growth rate of total food production in Nigeria. From a negative percentage growth from 1970 - 1980 (Table 1) the percentage growth rate of total food production in Nigeria increased exponentially from $1981-1993$. The period of improved total food production growth rate coincided with the period of government colossal funding of organized agricultural extension intervention in Nigeria.

Table 1: Percentage growth rate of total food production in Nigeria (1970 1993)

\begin{tabular}{lc}
\hline Period & Percentage (\%) growth rate \\
\hline $1970-1975$ & -1.74 \\
$1976-1980$ & -4.41 \\
$1981-1985$ & 9.31 \\
$1986-1990$ & 14.55 \\
$1991-1993$ & 5.71 \\
\hline
\end{tabular}

Source: CTA/DAC - ABU National Workshop Manual (1998) p. 16 Edited by Shaib, B; Aliyu, A. and Bakshi, J. S. Published by National Agricultural Research Strategy, NAPP, 1997.

Following the expiration of the donor funding arrangement, the extension system and its service delivery mechanism have become comatose. Arokoyo (1998) based on Christoplus stated aptly that agricultural extension today is in a crisis because of the changing world driven by globalization and stiffly competitive economy. Zulberti (2001) agreed that in many low-income and developing countries, agricultural and rural extension is in disarray due to the tension that exists between the modern force of globalization and the traditional force of culture, geography and community. Agricultural extension at present is not sufficiently responsive to the poor farmers' need nor financially sustainable (Conroy, 2003). There is a need for fundamental changes in extension delivery and funding (PED, 2000).

Indeed current changes such as globalization, climatic change, etc. has thrown various challenges to the survival of agricultural extension. The questions that need adequate answers arise. What is globalization? What is public and private good agricultural information? What kind of agricultural extension commodification does Nigeria need? How could the concept of agricultural extension be expanded to sustainably enhance the marketing of agricultural information?

\section{Globalization}

Globalization is the intensification of world-wide social relations which links distant localities in such a way that local happenings are shaped by events occurring miles away and vice versa (Giddens, 1990). Globalization seeks to achieve integration of national economies and removal of trade barriers resulting into development of an international mass culture and homogenization of social practices and culture. Globalization is extrinctly linked to privatization with attendant high competitive global market spiced with trade liberalization placing developing countries at a disadvantage in the global market (FAO, 2001). Globalization has tremendous benefits to the developed world but to developing world it is a form of neocolonialism. Indeed, globalization is dependency theory in action. With the advent of globalization extension of agricultural information is defined in terms of public good or private good. 


\section{Agricultural Information as Public Good and Private Good}

Information and knowledge can be treated as a commodity in knowledge networks along with the legal privatization of conventional extension and research institutions (Rivera and Zijp, 2002). Daku (1997) and Ozor (2006) based on extant literature noted that in welfare economic theory, agricultural information can be characterized as public and private good. The principles of excludability and subtractability determines whether a good or service is public or private good. Excludability applies when access is denied to those who have not paid for a produce or service while subtractability applies when one person uses or consumes a service or good and reduces its availability to others (Feldman, 1980; Kessides, 1992). A pure public good is characterized by low excludability and subtractability. Private firms will not be willing to provide these services because they are not profitable. On the other hand, a pure private good is characterized by high excludability and subtractability. These properties can be owned by individuals after paying a price. The characteristically high excludability and subtractability of private goods enables private firms to capture reasonable returns on their investments and given competitive markets to supply the goods at optimal levels, (Umali and Schwartz, 1994).

Increasingly, privatization has become an imperative in the global economy. Indeed, agricultural information has become one way of reducing poverty. This change towards information commodification reflects the privatization of information and agricultural industrialization (Wolf, 1998, FAO, 2001). Apart from the immediate value of educating the rural people in the value of practical income generating agricultural information, privatization as coping mechanism, will enable farmers to reach a financial level at which they can pay for extension services.

\section{The Agricultural Extension Commodification that Nigeria Need}

For Nigeria a hybrid type of extension commodification is recommended where agricultural information can be administered as both a public good and private good. This is based on the social challenges and the subsistent nature of rural farming in Nigeria. On the hand, extension must be made sustainable to survive in the present global economy hence the need to privatize some agricultural education services.

\section{Expanded Concept of Agricultural and Rural Extension}

(a) Expanded concept of agricultural and rural extension as a public good.

I. The Case of HIV/AIDS Pandemic and Extension.

Nigeria has the highest number of HIV/AIDS infected adults in West Africa (UNAIDS, 2004). The impact of HIV/AIDS has been particularly severe on small holder agriculture (Daudu, Okwu and Shaibu, 2006) but is increasingly affecting commercial agriculture (Topouzis, 2000). Training on agricultural production by agricultural extension need to give more emphasis on labour and capital saving technologies to compensate for labour shortage, gender appropriate agricultural practices, crop diversification and reduction in external input requirements (Topouzis, 2000). According to Mutanzadura, Mukurazita and Jackson (1999) and Topouzis (2000) agricultural production techniques which extension could utilize to mitigate the effect of HIV/AIDS Pandemic include; 
- Intercropping to reduce weeding time

- Use of crop varieties that are not labour intensive and are high yielding, earlymaturing and/or disease resistant as well as being early harvested and pounded thus requiring less labour.

- Zero or minimum tillage to reduce the need for high cost ploughs and oxen.

- Integrated pest management that can be used by women, the elderly and youths i.e. lighter ploughs and planters with modified hoes.

- Improved indigenous technologies in mulching, intercropping and seed selection.

- Improved technologies for animal husbandry.

\section{Mentoring of Young HIV/AIDS Orphaned Farmers}

Loss of skills, knowledge and experience brought about by the HIV pandemic needs to be considered in planning training programme. This is a new challenge to extension because the socialization of youths used to be the prerogative of parents and grand parents (Topouzis, 2000).

\section{Expanded Concept of Agricultural and Rural Extension as a Private Good}

According to FAO (2001), agricultural and rural extension could be conceived not purely as a production service but as an educational service so that revenue could be generated from the marketing of the information for sustainability of agricultural extension service delivery. The agricultural and rural extension concept could be expanded to include marketing extension, non-farm micro-enterprise development, provision of educational services to farmers' associations, technical extension and urban extension (FAO, 2001).

\section{Marketing Extension}

Agricultural marketing can be defined as the provision of farmers with the know-how regarding activities from production (some like Narayanan, (1991) says from post harvest) to sale, to enable them get their output to market most effectively (Karundasa, 1996). In this regard, it includes activities related to rural credit, insurance, agricultural input transportation, processing and storage of agricultural products, legal activities related to land tenure, land reform, quality control, subsidies and collective activities of farmers such as cooperatives and farmers' organizations. Indeed, marketing extension provides marketing intelligence, information on government policy, advice on post harvest practices, strategies of product marketing and prices. Market extension on the other hand, provides information on variations in commodity process, knowledge about where to sell some products, quality, availability and prices of inputs and actual competition in the market. Extension service could harness the provision of market information service to clients at a cost to achieve financial sustainability. According to Narayanan (1991), marketing extension can be undertaken by private or pubic institutions though the actual marketing of agricultural products can be better undertaken by the private sector.

\section{Non-Farm Rural Micro-Enterprise Development}

The appeal of the non-farm rural micro-enterprise development is that rural livelihood is not solely dependent on agriculture. Extension could teach farmers on the know-how of managing agricultural related micro-enterprise in the rural areas in 
order for them to generate off-farm income to promote their livelihood. In the process, extension service could generate income through private provision of this information to remain relevant and sustainable.

\section{Farmers' Organization}

Extension can also help farmers and produce processors to organize themselves to meet their agricultural interests through group formation and group organizations to enhance people's participation in development. Extension can reduce overhead cost and achieve sustainable service delivery not by working directly with farmers but by working indirectly with and through farmers' group or organizations $(\mathrm{FAO}, 2001)$.

\section{Technical Extension}

Apart from the traditional function of extension on technical extension service delivery, agricultural extension could provide information on issues as food storage development, processing, farm management and marketing even in programmes designed to enhance agricultural crop production (FAO, 2001). In the same manner agricultural extension could develop programmes in livestock development, forest use and conservation, fisheries engineering and capture, food and nutrition. These information could be marketed where feasible.

\section{Urban Extension}

The world is increasingly becoming urbanized. In Nigeria and other developing countries youths, the potential farmers, are increasingly migrating to the urban areas in search of better means of livelihood. Urban extension is a potential area for information transfer. Extension could market educational services for sustainability to migrant rural youth. According to FAO (2001) such programmes could include food security, employability of youth in the food industry, environmentally sound practices by small urban businesses and other food and agriculture related programmes.

\section{Conclusion and Recommendations}

The world and its environment are changing which implies that extension must change in tandem with these developments to remain relevant and sustainable. This paper attempts to identify some of the new roles that extension services need to play. Extension roles should not remain purely as an agricultural production service but as an educational commodity which can be sold at a price to its clients to ensure economic sustainability. However, it must retain some of its public roles which shall be phased out with time. It is recommended that extension field staff be retrained in technical, farm and business management etiquette of providing private extension educational service. Concomitantly field staff needs to be provided transport and logistic support to accomplish this vision.

\section{References}

Arokoyo, T. (1998). The Changing Roles of Agricultural Extension for Sustainable Development. In: Arokoyo, T.( Ed.) CTA/DAC - ABU National Workshop on the Challenging Role of Agricultural Extension (for Teachers of Extension at the Sub-Degree Level) Held at Ahmadu Bello University, Zaria. June $22-26^{\text {th }}$ 1998. 
Baxter, M. (1989). Investments in Agricultural Extension. In: Kesseba A. M. (Ed). Technology Systems for Small Farmers. London, West View Press.

Birkhaeuser, D., Evenson, D. E. and Feder, G. (1988). The Economic Impact of Agricultural Extension: A Review (World Bank Working Paper). Washington DC.

CTA/DAC - ABU National Workshop Manual on (1998). National Workshop on Challenging Role of Agricultural Extension (For Teachers of Extension at the Subdegree Level) Held at Ahmadu Bello University, Zaria. June $22-26^{\text {th }}$ 1998.

Conroy, C. (2003). New directions for Nigeria's Basic Agricultural Services. A Discussion Paper. National Workshop on Nigeria's Basic Agricultural Services. Vol. I( main Report) held at ABUJA FMARD.

Daku, Lefter (1997). Investing in Agricultural Extension: The Case of Albania. M.Sc. Research Project. Virginia Polytechnic Institute and State University Blacksburg, Virginia. August 1997.

Daudu S, Okwu, O. J. and Shaibu, N. (2006). The Effect of HIV/AIDS Scourge on Farm Families in Makurdi Local Government Area of Benue State, Nigeria. J. Hum. Eco. 19 (1): 41 - 44.

FAO (2001). Agricultural and Rural Extension Worldwide. Options for Institutional Reforms in the Developing Countries. Rome. FAO.

FeldMan A. M. (1980). Welfare Economics and Social Choice Theory. Boston. Cluwer Nijhoff Publishing.

Fresco, L. O. (1999). Foreword to: Communication in Extension: A Teaching and learning Guide by Carey, H. A. Rome. Food and Agriculture Organization of the UNO.

Giddens, A. (1990). The Consequence of Modernity. Cambridge's Policy

Press. P. 64.

Karunadasa, K. (1996). Marketing Extension: How can Extension help Small Farmers in Marketing and Supply? And who should be doing it? The rural Extension Bulletin. University of Reading Agricultural Extension and Rural Development Department. No. 9 April, 1996 p. 3 - 6.

Kessieles, C. (1992). Institutional Options for the Provision of Infrastructure. World Bank Discussion Paper 212 Washington, D. C.

Leagans, J. P. (1961). Extension Education for Community Development. In: Kamath, M. G. (Ed). Extension Education in Community Development. India. Glasgow Printing Co. P $1-26$.

Mutanzadura, G., Mukurazita, D. and Jackson, H. (1999). A Review of Household and Community Coping Response to HIV/AIDS epidemic in the Rural Areas of Sub-Saharan Africa. UNAIDS Best Practices Paper, June 1999. New York. UNAIDS. P. 25.

Narayanan, A. (1991). Enhancing Farmers' Income through Extension Services for Agricultural Marketing. In: Rivera, W. R. and Gustafson, D. J. (Eds.) Agricultural Extension World Wide Institutional Evolution and Forces for Change. Amsterdam: Elsevier Science Publishers.

Ozor, N. (2006). Cost Sharing as an Alternative Approach to Financial Agricultural Technology Transfer in Nigeria.Ph.D thesis. Agricultural Extension Department. University of Nigeria, Nsukka. 
PED (2002). Report of the Professional Extension Dialogue held in NAERLS, ABU, Zaria. July $29^{\text {th }}-31^{\text {st }} 2002$. Organized by Projects Coordinating Unit, Federal Ministry of Agriculture and Rural Development.

Rivera, W. M. and Zijp, W. (eds.) (2002). Contracting for Agricultural Extension: International Case Studies and Emerging Practices. United Kingdom and New York. CABI Publishers $188 \mathrm{pp}$.

Topouzis, D. (2000). The Impact of HIV/AIDS on Agriculture and Rural Development: Implication for Training Institutions. Human Resources in Agriculture and Rural Development. Rome. FAO. P. 93 - 103.

UNAIDS (2004). Report on the Global HIV/AIDS Epidemic, Genera. UNAIDS.

Umali, L. L. and Schwartz, L. (1994). Public and Private Agricultural Extension beyond

Traditional Frontiers. World Bank Discussion Paper: No. 236, Washington, D. C. The World Bank. 85pp.

Wolf, S. A. (ed.) (1998). Privatization of Information and Agricultural Industrialization. Boca Raton. FL: CRC Press.

Zulberti, E. (2001). Preface to Agricultural and Rural Extension World Wide Options for Institutional Reform in the Developing Countries. Rome FAO. 